\title{
SOWING DATE AND RATE EFFECT ON WINTER OILSEED RAPE (BRASSICA NAPUS L.) YIELD COMPONENTS' FORMATION
}

\author{
Oskars Balodis $^{\#}$ and Zinta Gaile \\ Faculty of Agriculture, Latvia University of Agriculture, Lielā iela 2, Jelgava, LV-3001, LATVIA \\ balodis.oskars@inbox.Iv; zinta.gaile@Ilu.Iv \\ ${ }^{\#}$ Corresponding author
}

Contributed by Zinta Gaile

\begin{abstract}
Crop yield per area is the product of plant density and productivity of an individual plant. Plant density and the time of winter oilseed rape sowing influences yield components (parameters of individual plant productivity), such as pod number per plant, seed number per pod, plant productivity, seed weight, and plant branching. The aim of this three-year (2008-2010) study was to investigate winter oilseed rape yield components depending on sowing date (five sowing dates) and sowing rate (four sowing rates for each variety) as initial cause of plant density at harvest for two type winter oilseed rape varieties (open pollinated 'Californium' and hybrid 'Excalibur'). Field trials were carried out at the Research and Study Farm "Vecauce" of the Latvia University of Agriculture. Winter oilseed rape yield components (pod number per plant and seed number per pod, plant productivity (seed number per plant and plant productivity in $g$ ) as well as the number of primary branches per plant) were affected $(\mathrm{p}<0.05)$ by sowing date and rate for both varieties. In general, no significant effect of sowing rate on 1000-seed weight was observed ( $\mathrm{p}>0.05)$, but sowing date influenced this component significantly $(\mathrm{p}<0.05)$. A yield compensation mechanism was demonstrated by significant $(\mathrm{p}<0.05)$ negative correlations between plant density at harvest and parameters of individual plant productivity.
\end{abstract}

Key words: winter oilseed rape, sowing date and rate, final plant density, yield components.

\section{INTRODUCTION}

It is important to understand winter oilseed rape (Brassica napus ssp. oleifera) yield components and their formation, because in Latvia this crop is affected by agro-meteorological conditions like severe winters or ones with frequent thaws, and specific field conditions. These variable conditions affect plant development and yield. Sowing date and rate affect plant development and yield to a large extent (Balodis and Gaile, 2012), but yield components have not been well documented yet in the conditions of Latvia.

Yield per area is the product of plant density, the number of pods per plant, the number of seeds per pod, and the individual seed weight (Diepenbrock, 2000). Yield of winter oilseed rape is determined by plant density (plant number per $\mathrm{m}^{2}$ ), which is affected by sowing rate, field germination, survival during winter and until harvesting, and by plant productivity (branch number per plant, pod number per plant, seed number per pod, and 1000 -seed weight). It is very important to understand the yield formation mechanism and factors that impact the winter oilseed rape yield.
Studies in Lithuania indicated that the best seed yield is obtained when plant density at harvest is $41-47$ plants per $1 \mathrm{~m}^{2}$ (Malinauskas, 2005). Positive correlation between the plant density at harvest and seed yield was observed in our preliminary study (Balodis and Gaile, 2009). Plant density in relation to the sowing rate particularly affects pod number per plant and seed number per pod (Taylor and Smith, 1992). Other investigations have shown that the number of pods per area was not significantly affected by plant density. However, the yield structure differs between varieties of oilseed rape (Jenkins and Leitch, 1986). Several literature sources indicate that the seed number per pod of winter oilseed rape plant is 14 to 21 seeds (Thurling, 1974; Liakas et al., 2005; Malinauskas, 2005). Zajac et al. (2011) reported that the pod location on the plant affects the seed number per pod. In Poland, studies on winter oilseed rape plant showed that $38 \%$ from pods were located on the main stem, and $62 \%$ on secondary branches (Wojtovicz et al., 1999). There is a lack of research available on the seed number per pod of oilseed rape plant in the conditions of Latvia, excepting a trial in 2006 that described seed number per pod for various oilseed rape varieties (Balodis et al., 2007). 
Flowering and seed formation is mainly affected by meteorological conditions in spring and summer periods. High air temperatures are crucial during oilseed rape reproduction growth stages (GS 61-79, BBCH) that affect plant productivity; the most vulnerable stage for the plant is flowering (Angadi et al., 2000).

Thurling (1974) reported a significant positive correlation between several yield structure elements in absolutely different growing conditions (in Australia). It was demonstrated that the number of pods per plant negatively correlated with the number of pods per unit area (Leach et al., 1999). Previous investigations showed that environmental conditions strongly influenced such elements as the pod number per area, seed number per pod, single seed weight, and they differed in field trials between year (Luthman and Dixon, 1987). Our preliminary results (Balodis and Gaile, 2009) showed similar tendencies.

The aim of this study was to describe winter oilseed rape yield components of two different type varieties (an open pollinated (line) and a hybrid) depending on sowing date and rate.

\section{MATERIALS AND METHODS}

Investigations were carried out with winter oilseed rape (Brassica napus ssp. oleifera) plants. Field trials with each winter rape variety (open pollinated 'Californium' and hybrid 'Excalibur') were carried out at the Research and Study Farm "Vecauce" (latitude: N $56^{\circ} 28^{\prime}$, longitude: E $22^{\circ} 53^{\prime}$ ) of the Latvia University of Agriculture. This paper focuses on yield components in the years from 2007/2008 to 2009/2010. The following factors were investigated:

\section{Factor A - five sowing dates:}

- 1 August (2 August 2007; 1 August 2008; 31 July 2009),

- 10 August (10 August 2007, 2009, 11 August 2008),

- 20 August (20 August 2007, 2009; 21 August 2008),

- 1 September (31 August 2007, 2009; 30 August 2008);

- 10 September (10 September 2007, 2009; 9 September 2008).

Factor B - sowing rate: $\mathrm{B} 1-120, \mathrm{~B} 2-100, \mathrm{~B} 3-80, \mathrm{~B} 4-$ 60 germinable seeds per $\mathrm{m}^{2}$ for 'Californium'; B1 - 80, $\mathrm{B} 2-60, \mathrm{~B} 3-40, \mathrm{~B} 4-20$ germinable seeds per $\mathrm{m}^{2}$ for 'Excalibur'.

Soils (by World Reference Base for Soil Resources) at the trial site were Endocalcaric Cambic Stagnic Phaeozem (Loamic) in 2008 and 2009, and Endocalcaric Stagnic Cambisol (Drainic, Hypereutric, Loamic, Novic) in 2010. Soil agro-chemical parameters slightly differed in trial years (Table 1), but overall conditions were suitable for winter oilseed rape growing.
Table 1

SOIL PARAMETERS AT TRIAL SITE

\begin{tabular}{l|c|c|c}
\hline \multicolumn{1}{c}{ Parameter } & \multicolumn{3}{c}{ Year } \\
\cline { 2 - 5 } & 2008 & 2009 & 2010 \\
\hline $\begin{array}{l}\text { Soil exchange reaction } \mathrm{pH} \mathrm{KCl} \\
\text { Plant - available P, } \mathrm{mg}^{-1} \mathrm{~kg}^{-1} \text { (by Egner - }\end{array}$ & 115 & 7.2 & 7.2 \\
$\begin{array}{l}\text { Rheem method) } \\
\text { Plant - available K, } \mathrm{mg} \cdot \mathrm{kg}^{-1} \text { (by Egner - }\end{array}$ & 194 & 169 & 111 \\
$\begin{array}{l}\text { Rheem method) } \\
\text { Organic matter, } \mathrm{g}_{\mathrm{kg}}{ }^{-1} \text { of soil (by Tiurin }\end{array}$ & 38 & 30 & 22
\end{tabular}

method)

The pre-crop was cereal mixture for silage in all trial years. Herbicide Raundap Gold s.c. (glyphosate, $450 \mathrm{~g} \cdot \mathrm{L}^{-1}$ ) 3.0 $\mathrm{L} \cdot \mathrm{ha}^{-1}$ was applied two weeks before traditional soil tillage with mould-board ploughing every year. Rototilling was performed before sowing. Sowing was done close (with one or two days deviation) to established dates; deviations in some occasions occurred due to inappropriate (mainly overly moist) soil conditions for sowing. Crops were fertilised with complex mineral fertilizers at the rate of $\mathrm{N} 12$ to $28 \mathrm{~kg} \cdot \mathrm{ha}^{-1}$, P 30 to $34 \mathrm{~kg} \cdot \mathrm{ha}^{-1}$, and $\mathrm{K} 75$ to $103 \mathrm{~kg} \cdot \mathrm{ha}^{-1}$ before sowing depending on a year and soil properties. Topdressing with nitrogen fertiliser at the rate of $70 \mathrm{~kg} \cdot \mathrm{ha}^{-1}$ of $\mathrm{N}\left(\mathrm{NH}_{4} \mathrm{NO}_{3}\right)$ in the beginning of the vegetation season, plus $70 \mathrm{~kg} \cdot \mathrm{ha}^{-1}$ of $\mathrm{N}\left(\left(\mathrm{NH}_{4}\right)_{2} \mathrm{SO}_{4}\right)$ at the stage of well-developed rosette (GS 30) was applied. Weeds were controlled applying herbicide Butisan Star s.c. (metasachlor, $333 \mathrm{~g} \cdot \mathrm{L}^{-1},+$ kvinmerac, $83 \mathrm{~g} \cdot \mathrm{L}^{-1}$ ), $2.5 \mathrm{~L} \cdot \mathrm{ha}^{-1}$ in $2007-2009$. Herbicide was applied when the oilseed rape was fully germinated in plots sown in the first three sowing dates in 2007 and 2008, and directly after sowing in 2009 for all trials. For plots sown on 1 September and 10 September in 2007, herbicide was not applied in autumn, but Lontrel 300 s.c. (clopiralid, $300 \mathrm{~g} \cdot \mathrm{L}^{-1}$ ) $0.5 \mathrm{~L} \cdot \mathrm{ha}^{-1}$ was sprayed in spring 2008. In the autumn of 2008, Butisan Star s.c. was used for rape sown on 1 and 10 September directly after sowing at the previously mentioned rate. To decrease the possible Sclerotinia stem rot (Sclerotinia sclerotiorum), fungicide Cantus d.g. (boscalid, $500 \mathrm{~g} \cdot \mathrm{kg}^{-1}$ ) $0.5 \mathrm{~kg} \cdot \mathrm{ha}^{-1}$ was used at full flowering (GS 65).

Yield components (plant density per $1 \mathrm{~m}^{2}$, pod number per sample, seed number per sample and branch number per sample) were determined at GS 85-88 from sample quadrats $\left(0.5 \mathrm{~m}^{2}\right)$ for all plots. Yield components (pod number per plant, plant productivity, seed number per pod) were calculated according to the methodology described by Malinauskas (2005).

For calculation of seed number per plant, formula (1) was used:

$S=1000 \times\left(\frac{P}{M}\right)$,

where: $\mathrm{S}$ - seed number per plant; $\mathrm{P}$ - plant productivity, g; $\mathrm{M}-1000$-seed weight, g. 
For calculation of seed number per pod, formula (2) was used:

$a=\frac{S}{A}$,

Where: a - seed number per pod; $\mathrm{S}$ - seed number per plant; A - pod number per plant.

Two-factor analysis of variance was used for statistical testing. Correlation analysis was also used.

Meteorological conditions. During the trial years, meteorological conditions for autumn, winter and summer periods differed considerably. Winters 2007/2008 and 2008/2009 had mild temperatures (Fig. 1) and sufficient snow cover; the plant survival of both cultivars was satisfactory. The winter of 2009/2010 was much more severe, resulting in poorest plant survival in the early sown plots, with plant density affected the most (Balodis and Gaile, 2015) and the sowing rate was not the main factor affecting plant density at harvest. The spring of 2010 caused poor plant survival for both varieties due to very moist soil conditions combined with relatively high air temperatures; all plants in several plots perished. Plants for both varieties sown on 10 September also suffered from high mortality, but especially for 'Californium', possibly because of low temperatures during winter in combination with the circumstance that late sown plants were poorly developed and not acclimatised for winter.

May is the month when precipitation and air temperature play the main role for successful plant development, as winter oilseed rape flowers and pods begin to form at that time. May was the poorest with precipitation in all trial years, but winter oilseed rape used moisture reserves suspended during winter, and growth and development of crop occurred without irregularities. However, very little precipitation was observed during the period from the $3^{\text {rd }}$ decade of April up to the $2^{\text {nd }}$ decade of June in 2008 (total $24.2 \mathrm{~mm}$ ). Total precipitation was only $18.0 \mathrm{~mm}$ from the $3^{\text {rd }}$ decade of April until the $1^{\text {st }}$ decade of June in 2009.

May of 2008 and 2009 had moderate temperatures (in the $3^{\text {rd }}$ decade of May $12.8^{\circ} \mathrm{C}$ in 2008 and $13.6^{\circ} \mathrm{C}$ in 2009), although already in the $2^{\text {nd }}$ decade of May 2010 mean air temperature was $16.1^{\circ} \mathrm{C}\left(\max .24 .8^{\circ} \mathrm{C}\right)$, which was signifi- cantly higher than in previous years. During pod development (GS 71-79) in June the average air temperatures were within the normal range (up to $16.3{ }^{\circ} \mathrm{C}$ in the $1^{\text {st }}$ decade in 2008; $17.4{ }^{\circ} \mathrm{C}$ in the $3^{\text {rd }}$ decade in $2009 ; 16.0{ }^{\circ} \mathrm{C}$ in the $3^{\text {rd }}$ decade in 2010) (Fig. 1). Extreme meteorological conditions were observed in July, 2010, with higher mean air temperatures (up to $22.6{ }^{\circ} \mathrm{C}$ in the $2^{\text {nd }}$ decade) (Fig. 1), and the maximal air temperature exceeded $28{ }^{\circ} \mathrm{C}$ for ten days in July, 2010, while precipitation in that month was $131.8 \mathrm{~mm}$ (compared to a long-term average of 75.0).

\section{RESULTS}

Yield of crop is formed by plant density and productivity of individual plants.

Plant density. The main cause of changes in plant density during winter was meteorological conditions. Wintering (plant density in spring versus plant density in autumn, expressed in \%) for 'Excalibur' was higher than for 'Californium'. The worst wintering was noted for late sowings (10 September) for both varieties in all three trial years, and among trial years in winter 2009/2010. Field trial results on changes of plant survival during the growth period of rape were described in details by Balodis and Gaile (2015).

Pod number per plant. Pod number per plant was significantly $(p<0.05)$ affected by sowing date and rate (as initial cause of plant density at harvest) for both varieties in 2008 and 2009. Pod number was higher at lower plant densities (Table 2). The year 2010 had atypical severe conditions for winter oilseed rape (see the section "Meteorological conditions" above). In 2010, the plant density was greatly affected by wintering conditions. For example, only one or two plants were collected in each quadrat $\left(0.5 \mathrm{~m}^{2}\right)$ for recording yield components in plots sown on 1 September with sowing rate 120 seeds per $\mathrm{m}^{2}$, respectively the pod number per plant reached 1740 to 2985 . However, this shows plant ability to compensate yield loss caused by perished plants (Table 2).

Seed number per pod. Seed number per pod was significantly $(p<0.05)$ affected by sowing date for both varieties in 2008 and 2009. The seed number per pod for 'Californium' varied from 23 seeds when sown on 1 August 2009

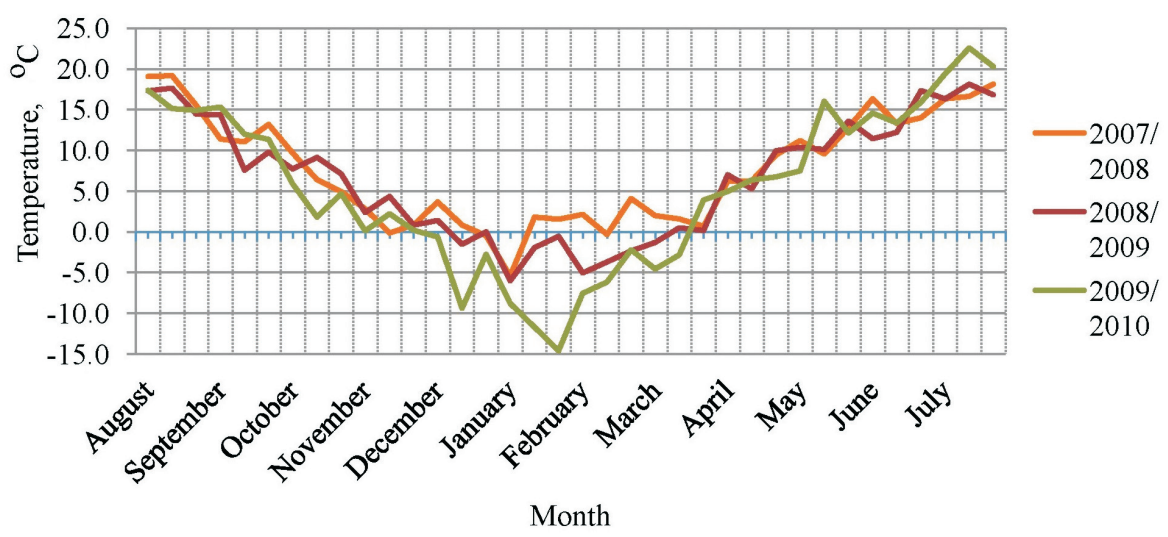

Fig. 1. Mean air temperature of each decade of month during growing period. 
Table 2

POD NUMBER PER PLANT OF WINTER OILSEED RAPE IN PLOTS SOWN USING DIFFERENT SOWING RATES (AVERAGE FROM FIVE SOWING DATES)

\begin{tabular}{c|c|c|c|c}
\hline Variety & Sowing Rate & 2008 & 2009 & $2010^{*}$ \\
\hline Californium & 120 & 77 & 73 & 520 \\
& 100 & 90 & 76 & 284 \\
& 80 & 106 & 130 & 454 \\
& 60 & 123 & 162 & 477 \\
& LSD $_{0.05}$ & 18.9 & 48.6 & $\times$ \\
\hline Excalibur & 80 & 111 & 125 & 291 \\
& 60 & 140 & 162 & 420 \\
& 40 & 180 & 253 & 902 \\
& 20 & 299 & 334 & 1332 \\
& LSD $_{0.05}$ & 44.6 & 57.0 & $\times$
\end{tabular}

* average from first four sowing dates for 'Californium'

to 17 seeds when sown on 10 September in 2008 (Fig. 2.). In both of these trial years, seed number per pod was lowest when rape was sown on the latest sowing date (10 September) for both varieties (Fig. 2). However, these differences were not observed in 2010 for both varieties. The seed number per pod for 'Excalibur' was 15 seeds when sown on 1 August and 19 seeds when sown on 10 August, and for 'Californium' 21 seed per pod when sown on 1 August and 22 seeds per pod when sown on 10 and 20 August and on 1 September.
Plant productivity in grams. Similarly to the seed number per pod, plant productivity (g) was significantly $(p<0.05)$ affected by sowing date and sowing rate (as initial cause of plant density) in 2008 and 2009. Obviously, the most productive plants were observed in plots with lower plant density (Fig. 3). Plants were much more productive in 2010 because of lower density caused by a severe winter. In 2008 and 2009, the average (from five sowing dates) plant productivity in half of cases was higher for 'Californium' for sowing rate 80 and 60 seeds $\left(80\right.$ seeds per $\mathrm{m}^{2}$ and $9.7 \mathrm{~g}$ in 2008, $15.2 \mathrm{~g}$ in 2009; 60 seeds per $\mathrm{m}^{2}$ and $12.6 \mathrm{~g}$ in 2008, $21.3 \mathrm{~g}$ in 2009), in comparison with 'Excalibur' (80 seeds per $\mathrm{m}^{2}$ and $10.2 \mathrm{~g}$ in 2008, $13.9 \mathrm{~g}$ in 2009; 60 seeds per $\mathrm{m}^{2}$ and $11.1 \mathrm{~g}$ in 2008, $23.9 \mathrm{~g}$ in 2009). The variety 'Californium' sown on 10 September did not survive in 2010, average plant productivity from four sowing dates showed that 'Californium' gave higher mean plant productivity in $\mathrm{g}$ when the above mentioned sowing rates were used (Fig. 3).

Plant productivity measured as seed number per plant. The seed number per plant, similar to other components was significantly $(p<0.05)$ affected by both sowing date and sowing rate (as initial cause of plant density) (Table 3). The seed number per plant of variety 'Californium' varied from 766 seeds per plant when oilseed rape was sown on 1 September using sowing rate 120 seeds per $\mathrm{m}^{2}$, up to 9975 seeds per plant when rape was sown on 1 August using sowing rate 60 seeds per $\mathrm{m}^{2}$ in 2009. The seed number per plant for 'Excalibur' was higher: from 1012 seeds per plant
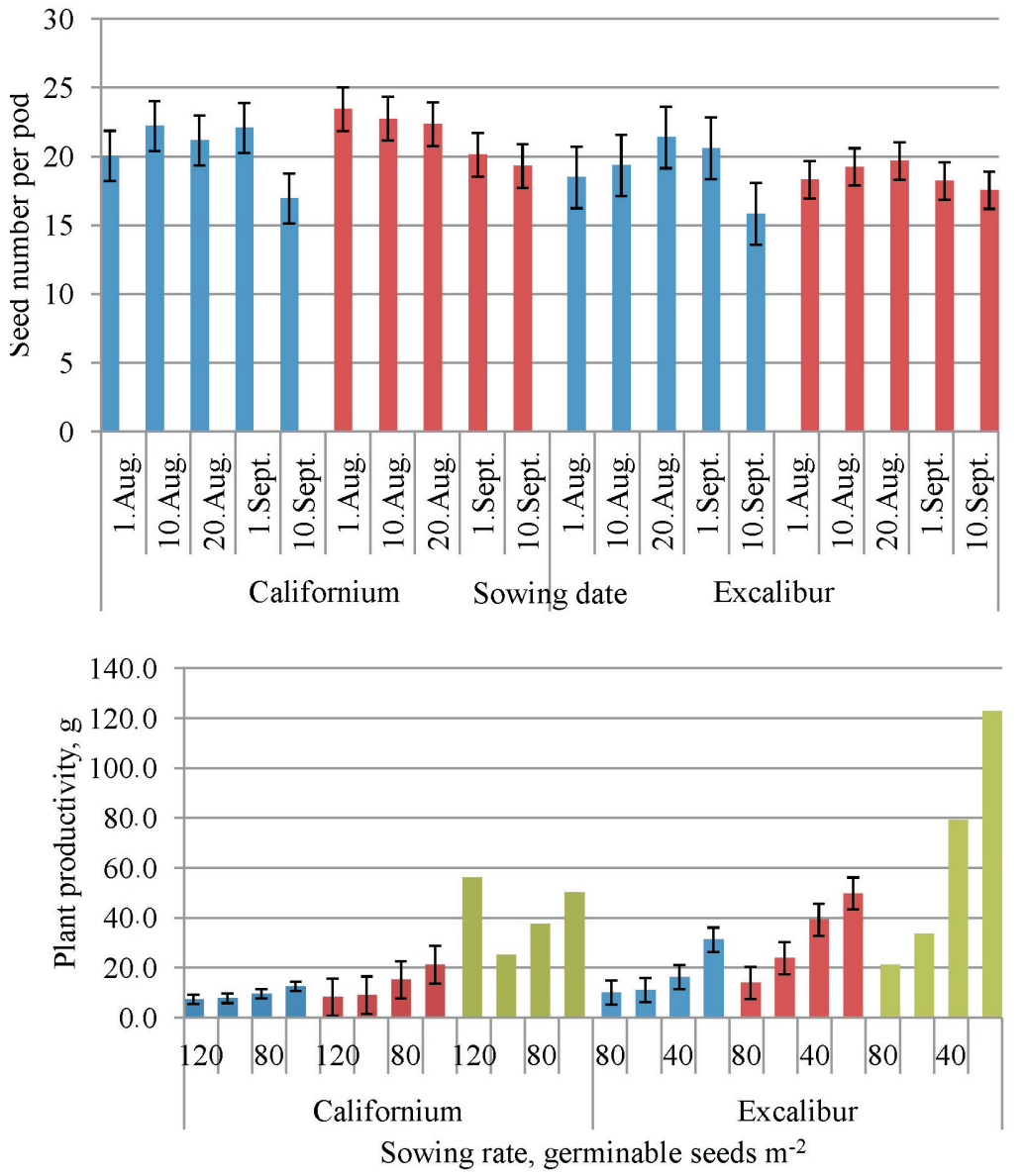

- 2008

- 2009

$-2008$

$\square 2009$

$\square 2010$
Fig. 2. Effect of sowing date on winter oilseed rape seed number per pod depending on the variety in 2008 and $2009(p<0.05)$.
Fig. 3. Effect of sowing rate (as initial cause of plant density) of two varieties of winter oilseed rape on plant productivity (g) in 2008, $2009(p<0.05)$ and 2010 (average from first four sowing dates for 'Californium'). 
SEED NUMBER PER PLANT OF WINTER OILSEED RAPE IN PLOTS SOWN USING DIFFERENT SOWING RATES DEPENDING ON THE VARIETY (AVERAGE FOR ALL SOWING DATES), 2009-2010

\begin{tabular}{c|c|c|c|c}
\hline Variety & Sowing Rate & 2008 & 2009 & $2010^{*}$ \\
\hline Californium & 120 & 1590 & 1505 & 7167 \\
& 100 & 1693 & 1661 & 2482 \\
& 80 & 2160 & 2809 & 7059 \\
& 60 & 2820 & 3925 & 21106 \\
& LSD $_{0.05}$ & 411.7 & 1425.4 & $\times$ \\
\hline Excalibur & 80 & 2178 & 2217 & 4854 \\
& 60 & 2406 & 2912 & 6649 \\
& 40 & 3415 & 4836 & 16569 \\
& 20 & 6527 & 6404 & 24050 \\
& LSD $_{0.05}$ & 1016.3 & 1154.3 & $\times$
\end{tabular}

* average from the first four sowing dates for 'Californium'

when rape was sown on 1 September 2009 using sowing rate 80 seeds per $\mathrm{m}^{2}$ up to 8949 seeds per plant when rape was sown on 20 August 2008 using sowing rate 20 seeds per $\mathrm{m}^{2}$.

The number of seeds per plant, as plant productivity measured in g, was much higher for all sowing rates in 2010 (Table 3), when plant density at harvest was decreased mainly by a severe winter and not affected by sowing rate at the same extent like in previous years.

Seed weight. An important winter oilseed rape yield component is seed weight expressed in grams of 1000 seeds. Thousand seed weight was significantly $(p<0.05)$ affected by sowing date in 2008 and 2009 for both varieties. The harvest year also affected 1000-seed weight: seeds were heavier in 2009 for both varieties (Table 4) when sufficient precipitation and mild air temperature was observed during the seed ripening period (GS 80-89). In general, there was no significant effect of sowing rate on 1000-seed weight, except on 1000-seed weight for 'Excalibur' in 2009.

Branch number per plant. Both sowing date and rate significantly $(p<0.05)$ affected number of primary branches per plant in 2008 and 2009 (Fig. 4). Plants produced most branches when sown on 1 August in all trial years. The number of primary branches per plant for 'Californium'
1000-SEED WEIGHT OF WINTER OILSEED RAPE AFFECTED BY SOWING DATE

\begin{tabular}{c|ccc|c|c|c|c}
\hline \multirow{2}{*}{$\begin{array}{c}\text { Sowing } \\
\text { date }\end{array}$} & \multicolumn{3}{|c|}{ Californium } & \multicolumn{3}{c}{ Excalibur } \\
\cline { 2 - 7 } & 2008 & 2009 & 2010 & 2008 & 2009 & 2010 \\
\hline 1 Aug. & 4.43 & 5.40 & 4.58 & 4.53 & 5.65 & 4.57 \\
10 Aug. & 4.38 & 5.47 & 4.67 & 4.44 & 5.71 & 4.57 \\
20 Aug. & 4.41 & 5.46 & 4.61 & 4.39 & 5.83 & 4.62 \\
1 Sept. & 4.65 & 5.74 & 4.38 & 5.08 & 5.74 & 4.66 \\
10 Sept. & 5.41 & 5.42 & $\times$ & 5.75 & 5.51 & 4.59 \\
LSD $_{0.05}$ & 0.140 & 0.141 & $\times$ & 0.095 & 0.118 & $\times$
\end{tabular}

varied from 9.2 when rape was sown on 1 August using sowing rate 60 seeds per $\mathrm{m}^{2}$ to only 1.9 branches per plant when rape was sown on 1 September using sowing rate 120 seeds per $\mathrm{m}^{2}$ in 2009. The lower sowing rate used for 'Excalibur' resulted in more branches per plant; the range was from 16.5 branches per plant when rape was sown on 1 August using the sowing rate 20 seeds per $\mathrm{m}^{2}$ in 2008 to only 2.0 branches per plant when sown on 1 September using 80 seed per $\mathrm{m}^{2}$ in 2009 . In 2010, when the plant density at harvest was decreased by a severe winter, the average branch number per plant was slightly higher. In 2010, the primary branch number per plant for 'Californium' varied from 17.1 when sown on 20 August using the sowing rate 60 seeds per $\mathrm{m}^{2}$ to 3.9 branches per plant when rape was sown on 10 August using the sowing rate 120 seeds per $\mathrm{m}^{2}$; in comparison, for 'Excalibur' there were 15.8 branches per plant when rape was sown on 10 August using the sowing rate 20 seeds per $\mathrm{m}^{2}$ and 4.8 branches per plant when rape was sown on 20 August using the sowing rate 80 seeds per $\mathrm{m}^{2}$. Ability of plants to produce additional branches was observed after the harsh winter in 2010 , to compensate seed yield.

Yield component compensation. Our results showed that plant density due to sowing rate affected most yield components. There was a significant positive correlation $(p<0.05)$ between plant density during harvest and yield for 'Californium' $\left(\mathrm{r}=0.590>\mathrm{r}_{0.01}=0.333, \mathrm{n}=56\right)$ and for 'Excalibur' $^{\prime}\left(\mathrm{r}=0.529>\mathrm{r}_{0.01}=0.333, \mathrm{n}=60\right)$.

Negative correlations (Fig. 5) between plant density during harvest and other yield components (the branch number per plant, pod number per plant, seed number per pod and plant,

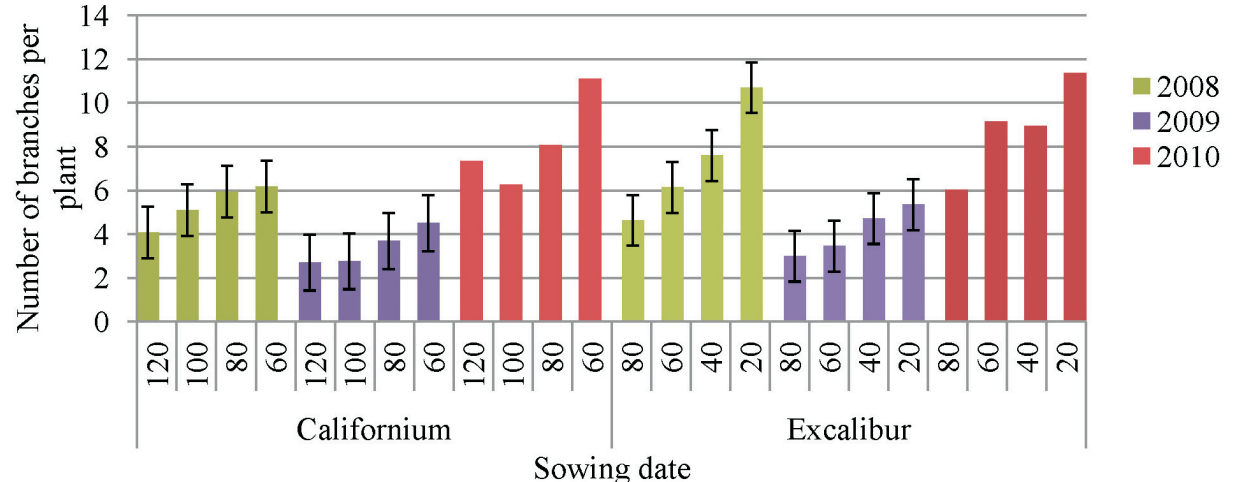

Fig. 4. Effect of sowing rate (germinable seeds $\mathrm{m}^{-2}$ ) of winter oilseed rape on average number of branches per plant for two varieties in 2008, $2009(p<0.05)$ and 2010 (average from first four sowing dates for 'Californium'). 


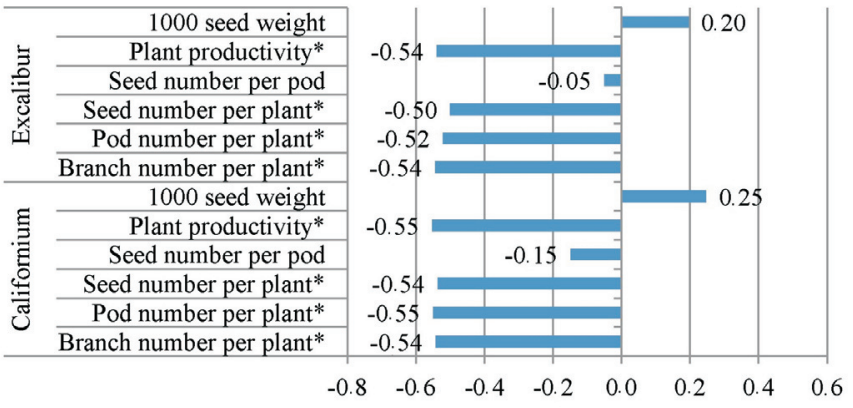

Fig. 5. Linear correlation coefficients $\mathrm{r}_{\mathrm{yx}}$ between the plant density during harvest $(\mathrm{x})$ and yield components $(\mathrm{y})$ for winter oilseed rape varieties 'Excalibur' and 'Californium', years 2008-2010: * correlation significant at $p<0.05$.

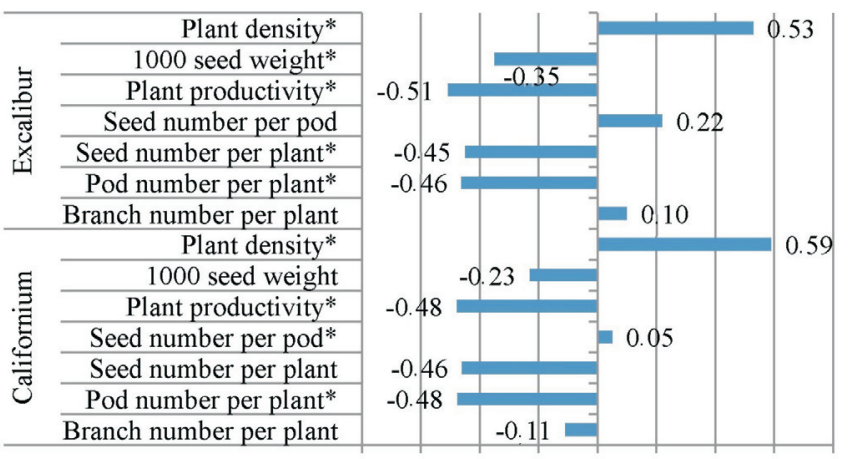

$\begin{array}{lllllllll}-0.8 & -0.6 & -0.4 & -0.2 & 0.0 & 0.2 & 0.4 & 0.6 & 0.8\end{array}$

Fig. 6. Linear correlation coefficients $\mathrm{r}_{\mathrm{yx}}$ between yield components (x) and seed yield (y) for winter oilseed rape varieties 'Excalibur' and 'Californium', years $2008-2010$ : * correlation significant at $p<0.05$.

and plant productivity in $\mathrm{g}$ ) indicate a yield compensation mechanism.

Some relationships between several yield components (parameters of an individual plant productivity) were observed. Correlation between branch number per plant and pod number per plant $\left(r=0.468>r_{0.05}=0.253\right)$, seed number per plant $\left(\mathrm{r}=0.476>\mathrm{r}_{0.05}=0.253\right)$ and plant productivity $(\mathrm{r}=$ $0.478>r_{0.05}=0.253$ ) were found only for 'Californium'. These relationships showed that plants at lower density produced more branches, resulting in higher individual plant productivity. Negative correlation between 1000-seed weight and primary branch number per plant was found for both varieties $\left(r=/-0.595 />r_{0.05}=0.253\right.$ for 'Californium'; $\mathrm{r}=/-0.561 />\mathrm{r}_{0.05}=0.253$ for 'Excalibur'). For 'Californium', we observed that 1000 -seed weight was lower when plants had more pods and seeds per plant: negative relationship between pod number per plant and 1000-seed weight $\left(\mathrm{r}=/-0.373 />\mathrm{r}_{0.05}=0.253\right)$, and seed number per plant and 1000 -seed weight $\left(\mathrm{r}=/-0.355 />\mathrm{r}_{0.05}=0.253\right)$.

Correlations between yield components and seed yield are shown in Figure 6. Positive correlation was found between plant density at harvest and seed yield, but significant $(p<$ 0.05 ) correlation between seed yield and all other yield components were negative, also demonstrating a compensation mechanism of two yield components (plant density and parameters of individual plant productivity).

\section{DISCUSSION}

Values of winter oilseed rape yield components had not been well documented in Latvia previously. Differences in the oilseed rape yield component "pods per plant" showed plant ability to compensate seed yield in cases when plant density was lower, such as due to decreased sowing rate and poor wintering). Wang et al. (2011) observed that the number of pods per plant depends on the number of developed pods and aborted pods, which vary depending on different pollination conditions. It is obvious in our experiment that the sowing rate, which is the initial cause of plant density at harvest, influenced the pod number per plant (Table 2). The pod number per plant was significantly $(p<0.05)$ affected in 2008 and 2009 by sowing date and rate for both varieties. Pod number increased at lower plant densities. The field trial results showed variability of yield components depending on each trail year. Our trial results are in agreement with Diepenbrock (2000) who reported that plant density had the greatest effect on yield components of individual plants. The effect of sowing date influence on yield components was shown by Luthman et al. (1987), who observed that later sown crops had fewer pods per plant (54 to 101) depending on the experimental year. This agrees with our experiment data. Investigations in different years and locations worldwide showed great variation of pod number per plant depending on specific conditions; e.g. Thurling (1974) reported 60-230 pods per plant in Australia, and Malinauskas (2005) reported 123-203 pods per plant in Lithuania. In several trials, the pod number per plant was above 100 pods when oilseed rape was sown in August (Luthman et. al., 1987; Diepenbrock, 2000), our previous research in Latvia showed that pod number per plant was significantly affected by rape variety, varying from 92-142 pods per plant depending on variety (Balodis et al., 2007). Plant density as the main factor affecting pod number per plant was particularly evident in our experiments in 2010 due to very poor plant wintering causing extremely low plant density (pod number per plant was 1332 pods for 'Excalibur' on average from all sowing dates). Other studies (Scaribrick et al. 1982; Sierts et al. 1987) showed that pod number per plant increased with decreasing plant competition. However, other factors can also affect the pod number per plant. Sieling et al. (1997) reported preceding crop effect on the pod number per plant, reaching from over 186 pods per plant at density 60 plants per $\mathrm{m}^{2}$ after peas-wheat. Additional foliar fertilisation of winter rape also increased the pod number per plant and 1000-seed weight in Lithuanian growing conditions (Liakas et al., 2005). Effect of growth regulator application differed depending on the experiment: increased number of pods per plant was observed by Leach et al. (1994), while application of fungicide-growth regulator did not increase significantly the pod number per plant in Latvia (Balodis et al. 2007). Abiotic stress (high temperatures during flowering) can also affect the number of pods per plant. Angadi et al. (2000) observed more pods per plant, but with less seeds; seed abortion was also more common in such conditions. 
In our experiment, the seed number per pod was significantly affected by sowing date (e.g., 17-23 seeds per pod for 'Californium' and 16-21 seeds per pod for 'Excalibur', Fig. 2) and sowing rate (as an initial cause of plant density) also affected seed number per pod for 'Californium' significantly in both trial years, but for 'Excalibur' only in 2008. Zajac et al. (2011), who reported mean number of seeds per pod of 19, considered that location of particular component on a plant was also important; more seeds per pod were found in the middle part of plant in comparison with upper and lower parts. Pod distribution within the crop canopy is influenced by plant density - at high density most pods occur on the upper branches (Leach et al., 1999). Despite the breeding efforts of oilseed rape in last decades, the seed number per pod has changed little; similar numbers of seeds per pod (14 to 21 seeds per pod) were observed in earlier studies (Thurling 1974) with later studies (Liakas et al. 2005, Malinauskas 2005, Zhang et al. 2012). However, the seed number per pod can increase up to 27 seeds on the main stem, in relation to pod location on the plant (Wang et al., 2011). Previous investigations in Latvia in 2006 showed that seed number per pod was 19 to 28 depending on the variety (Balodis et al., 2007). In Poland, Bocianowski et al. (2014) also showed higher average seed number per pod: 20.7-30.9 depending on the variety at density 80 plants per $\mathrm{m}^{2}$ and trial location. In our experiment the seed number per pod was significantly $(p<0.05)$ affected by sowing date for both varieties in 2008 and 2009, but lower seed number per pod in later sowings was not always observed. Jenkins and Leitch (1986) found that seed number per pod decreased in earlier sowing. In our experiment sowing rate affected seed number per pod for 'Californium' in both trial years, and for 'Excalibur' in 2008, but sowing rate was only an initial cause of plant density at harvest. Zhang et al. (2012) reported that seed number per pod of winter oilseed rape was significantly lower at higher plant densities.

Seed number per plant depended on pod number per plant and seed number per pod. In our trial the seed number per plant was significantly $(p<0.05)$ affected by sowing date and rate as an initial cause of plant density at harvest. At lower plant densities the seed number per plant increased for both varieties. The seed number per plant in 2010 differed from that in 2008 and 2009 (Table 3) due to lower density after a severe winter; in several cases only one or two plants per $\mathrm{m}^{2}$ were recorded. At these low densities, the oilseed rape plant showed the ability to compensate yield with more pods per plant. Significant sowing rate effect on 1000 -seed weight mainly was not observed in our experiment; the only exception when a significant impact on this parameter was observed was in the year 2009 for 'Excalibur'. In a previous experiment, 1000-seed weight was not affected by the seed rate treatments (Scarisbrick $e t$ al., 1982), but in that study much higher sowing rates (up to 13.5 and $18.0 \mathrm{~kg}$ per ha) depending on trial year were used. Sierts et al. (1987) also reported that 1000-seed weight varied slightly depending on plant density and row spacing. The 1000-seed weight was different depending on the pod size (number of seeds per pod) and their location along the stem (Zajac et al., 2011). Wojtovicz et al. (1999) and Mathieu et al. (2011) also reported that seeds were heavier on the main stem if comparison with those on branches. Our experiment data showed that 1000 -seed weight was significantly $(p<0.05)$ affected by sowing date in 2008 and 2009 for both varieties, but changes of 1000-seed weight were not very regular. In 2008, seeds were heavier when rape was sown in September for both varieties (Table 4). In 2009, 1000-seed weight was significantly higher only when sowing was done on 1 September for 'Californium', but for 'Excalibur' 1000-seed weight was significantly lower only when rape was sown on 10 September. Luthman et al. (1987) reported that 1000 -seed weight was not greatly affected by delayed sowing, but there were indications that the oilseed rape on the earliest sown plots had the heaviest seeds. Comparatively similar was 1000 -seed weight in variants sown at different sowing times in 2010 in our trial. It was observed that 1000-seed weight was different among the trial years. Waymann et al. (2015) explained similar observation in a wide range of environments (in total 34 environments - site $\times$ year combinations) in Germany, and showed that air temperature during seed development significantly affected 1000-seed weight.

Plant productivity $(\mathrm{g})$ of winter oilseed rape depends on plant density, pod number per plant, seed number per plant and seed weight. These yield components were affected by our investigated factors. Our experiment showed that plant productivity was significantly $(p<0.05)$ affected by sowing date and rate (as initial cause of plant density at harvest) in 2008 and 2009. Plants were more productive at lower plant densities, up to $21.3 \mathrm{~g}$ for 'Californium' when sown at 60 seeds per $\mathrm{m}^{2}$ in 2009 and $49.8 \mathrm{~g}$ for 'Excalibur' when sown at 20 seeds per $\mathrm{m}^{2}$ (Fig. 3). The mean plant productivity was much higher in less dense crops, particularly in 2010, reaching 122 g per plant for 'Excalibur' (Fig. 3) when 20 seeds per $\mathrm{m}^{2}$ were sown. However, plant density at harvest was very low due to a severe winter. Thus, high plant productivity was gained mainly because of plant ability to produce more fertile branches. Winter oilseed rape plant is characterised by high ability to generate more branches in poor density crop. Both sowing date and rate (as initial cause of plant density at harvest) significantly $(p<0.05)$ affected the number of primary branches per plant in 2008 and 2009. Plants produced the greatest number of primary branches when sown on 1 August in all trial years. In all trial years, plants produced more branches when sown on earlier sowing dates and with a lower sowing rate. In previous studies, a later-sown crop was less advanced than earlier-sown ones (Luthman et. al., 1987) and primary branch numbers were significantly decreased with increased plant density (Zhang et al., 2012).

It is important to determine the relationships between yield and different yield components. The results clearly indicated an oilseed rape yield compensation mechanism in our conditions. Decades ago, Thurling (1974) reported a significant positive correlation between number of pods per plant 
and seed yield, number of pod-bearing branches per plant and seed yield, and the number of pods per branch and seed yield. A tight positive correlation between number of branches per plant and number of pods per plant was also found. In addition, correlation between the number of seeds per pod and seed yield were positive, as observed previously by Basama (2008). Sierts et al. (1987) reported that the yield compensation performed better in a narrow row spacing than in a wider row spacing. Our experiment clearly showed that lower plant densities resulted in increased values of other yield components (Fig. 5), this regularity was valid when calculated from two year data (2008 and 2009) as well as if data of untypical year 2010 were added. Investigation of the oilseed rape yield compensation mechanism is very important in different aspects, for example, regarding insect pests and their damage. Williams (1979) reported oilseed rape yield compensation resulting in no yield loss at maximum seed weevil (Ceutorhynchus assimilis) infestation of $25 \%$ of pods, from removal of $60 \%$ of pods or from removal of up to half of its flowers. Nutrition aspects of oilseed rape are also important, as the amount of available assimilates are a primary determinant of pod and seed production during the period of flowering and pod setting (Wang et al., 2011). Climate change can also affect oilseed rape growing. Temperature stress can affect oilseed rape growth and formation of yield components. High temperature stress can injure plant reproductive organs. A temperature of $35{ }^{\circ} \mathrm{C}$ for seven days caused heat stress, which resulted in a yield decrease to $52 \%$ (Angadi et al., 2000); however, the highest temperature observed in our trial years was a three day period in 2010 above $30{ }^{\circ} \mathrm{C}$ in July. Waymann et al. (2015) reported that during seed development only temperature has a significant effect on yield.

The investigated winter oilseed rape yield components (the pod number, seed number per plant, plant productivity $(\mathrm{g})$, 1000 -seed weight, as well as the number of primary branches per plant) were affected by sowing date and sowing rate (as initial cause of plant density at harvest) for both varieties: open pollinated 'Californium' and hybrid 'Excalibur'. Sowing rate affected seed number per pod for 'Californium' (line) in both trial years, but for 'Excalibur' (hybrid) only in the year 2008. Individual plants were more productive at lower plant densities. The seed number per plant was significantly $(p<0.05)$ affected by sowing date and rate. In general, a significant impact of sowing rate on 1000 -seed weight was not observed $(p>0.05)$. Plant density was the main factor affecting other specific yield components. A yield compensation mechanism was demonstrated by significant $(p<0.05)$ correlations between the plant density during harvest and other yield components.

Seed yield is a function of the number of plants per unit area, pod number per plant, seed number per pod and seed weight. While yield compensation was observed, plant density was still the main yield component that affected yield for both varieties, shown by significant positive correlations between plant density during harvest and seed yield. McGregor (1987) found that seed yield was not directly proportional to plant density over the range of densities, which agrees with our trial. Still the minimum plant density for good yields in our conditions is under question. In several studies eight plants per unit indicated that there was no appreciable plant compensation limiting individual plant growth at these densities; therefore, there is no potential for compensation (Mendham et al., 1981; McGregor 1987). Results from the present study can aid further understanding of the variation in yield components of oilseed rape in conditions of Latvia.

\section{REFERENCES}

Angadi, S. V., Cutforth, H. W., Miller, P. R., McConkey B. G., Entz, M. H., Brandt, S. A., Volkmar, K. M. (2000). Response of three Brassica species to high temperature stress during reproductive growth. Canadian J. Plant Sci., 80, 693-701.

Balodis, O., Gaile, Z., Bankina, B. Vītola, R. (2007). Fungicide application effect on yield and quality formation of winter oil-seed rape (Brassica napus L.). In: Proceedings of Annual $13^{\text {th }}$ International Scientific Conference ,, Research for Rural Development 2007”. Latvia University of Agriculture, Jelgava, pp. 14-21.

Balodis, O., Gaile, Z. (2009). Dažu agronomisko faktoru ietekme uz ziemas rapša (Brassica napus L.) ražu un tās struktūrelementu veidošanos [Influence of some agronomical factors on formation of winter oilseed rape (Brassica napus L.) yield and its components]. Grām.: Ražas svētki „Vecauce - 2009”: Latvijas Lauksaimniecības universitātei - 70. Zinātniskā semināra rakstu krājums [Harvest Fest „Vecauce - 2009”: Latvia University of Agriculture - 70. Proceedings of the Scientific Seminar]. Jelgava, LLU, pp. 9-12 (in Latvian).

Balodis, O., Gaile, Z. (2012). Oilseed rape (Brassica napus ssp. oleifera) seed yield depending on several agro-ecological factors. In: Proceedings of the International Scientific Conference „Renewable Energy and Energy Efficiency”. Latvia University of Agriculture, Jelgava, pp. 39-45.

Balodis, O., Gaile, Z. (2015). Changes of winter oilseed rape plant survival during vegetation. Proceedings of the Latvia University of Agriculture, 33, $35-45$.

Basama, D. (2008). The correlation and path analysis of yield and yield components of different winter rapeseed (Brassica napus ssp. oleifera L.) cultivars. Res. J. Agricult. Biol. Sci., 4 (2), 120-125.

Bocianowski, J., Liersch, A., Bartkowiak-Broda, I. (2014). Variability of the agronomic traits of different oilseed rape cultivars (Brassica napus L.). Jokull J., 64 (9), 62-71.

Diepenbrock, W. (2000). Yield analysis of winter oilseed rape (Brasica napus L.): A review. Field Crops Res., 67, 35-49.

Jenkins, P. D., Leitch, M. H. (1986). Effects of sowing date on growth and yield of winter oil-seed rape (Brassica napus). J. Agr. Sci.., 105, 405-420.

Leach, J. E., Darby, R. J., Williams, I. H., Fitt, B. D., Rawlinson, C. J. (1994). Factors affecting growth and yield of winter oilseed rape (Brassica napus), 1985-89. J. Agr. Sci., 122, 405-413.

Leach, J. E., Stevenson, H. J., Rainbow, A. J., Mullen, L. A. (1999). Effects of high plant populations on the growth and yield of winter oilseed rape (Brassica napus). J. Agr. Sci., 132, 173-180.

Liakas, V., Malinauskas, D., Šiuliauskas, A. (2005). Impact of the additional leaf spray fertilization of rape on the yield and its structural elements. Latvian J. Agron., 8, 112-117.

Luthman, P. W. J., Dixon, F. L. (1987). The effect of drilling date on the growth and yield of oil-seed rape (Brassica napus). J. Agr. Sci., 108, 195-200. 
Malinauskas, D. (2005). Peculiarities of Winter Rape Growth, Development and Ripening in Central Lithuania. Summary of Doctoral Dissertation. Lithuanian University of Agriculture, Kaunas, 26 pp.

Mathieu, A., Cournede, P. H., Allirand, J. M., Jullien, A., Reffrye, P., Zhang, B. G., Wang, X. (2011). Effects of pod position and its appearance time on pod and seed abortion in winter oilseed rape (Brassica napus L.). In: Proceedings of $13^{\text {th }}$ Rapeseed Congress, 5-9 June 2011. Prague, Czech Republic, pp. 154-157.

McGregor, D. I. (1987). Effect of plant density on development and yield of rapeseed and its significance to recovery from hail injury. Canadian $J$. Plant Sci., 67, 43-51.

Mendham, N. J., Shipway, P. A., Scott, R. K. (1981). The effect of seed size, autumn nitrogen and plant population density on the response to delayed sowing in winter oil-seed rape (Brassica napus). J. Agr. Sci., 96, 417-428.

Sieling, K., Christen, O., Nemati, B., Kanus, H. (1997). Effects of previous cropping on seed yield and yield components of oil-seed rape (Brassica napus L.). Eur. J. Agron., 6, 215-223.

Sierts, H. P., Geisler, G., Leon, J., Diepenbrock, W. (1987). Stability of yield components of winter oil-seed rape (Brassica napus L.). J. Agron. Crop Sci., 158, 107-113.

Scarisbrick, D. H., Daniels, R. W., Noorrawi A. B. (1982) The effect of varying seed rate on the yield and yield components of oilseed rape (Brassica napus). J. Agron. Crop Sci., 99, 561-568.

Taylor, A. J., Smith, C. J. (1992). Effect of sowing date and seeding rate on yield and yield components of irrigated canola (Brassica napus L.) grown on a red-brown earth in South-Eastern Australia. Austral. J. Agricult. Res., 43, 1629-1641.

Thurling, N. (1974). Morphological Determinats of Yield in Rapseed (Brassica campestris and Brassica napus). II Yield Components. Austral. J. Agricult. Res., 9, 711-721.

Zajac, T., Oleksy, A., Stoklosa, A., Klimek-Kopyre, A. (2011). Comparison of morphological traits, productivity and canopy architecture of winter oilseed rape (Brassica napus L.) and white mustard (Sinapis alba L.). J. Applied Bot. Food Quality, 84, 183-191.

Zhang, S., Liao, X., Zhang, C., Xu, H. (2012). Influences of plant density on the seed yield and oil content of winter oilseed rape (Brassica napus L.). Industr. Crops Prod., 40, 24-32.

Wang, X., Mathieu, A., Cournčde, P. H., Allirand, J. M., Jullien, A., Reffye, P., Zhang, B. G. (2011).Variability and regulation of the number of ovules, seeds and pods according to assimilate availability in winter oilseed rape (Brassica napus L.). Field Crops Res., 122, 60-69.

Waymann, W., Böttcher, U., Sieling, K., Kage, H. (2015). Effects of weather conditions during different growth phases on yield formation of winter oilseed rape. Field Crops Res., 173, 41-48.

Williams, I. H., Free J. B. (1979). Compensation of oilseed rape (Brassica napus L.) plants after damage to their buds and pods. J. Agricult. Sci., 92, 53-59.

Wojtowicz, M., Wielebski, F., Krzymanski, J. (1999). Yield structure of double low winter oilseed rape (Brassica napus L.) varieties in different environmental conditions. In: Proceedings of $10^{\text {th }}$ International Rape Congress, 26 September 1999. Canberra, Australia, GCIRC. Available at: http://www.regional.org.au/au/gcirc/4/302.htm (accessed 6 March 2016).

Received 20 March 2016

\section{SĒJAS LAIKA UN IZSĒJAS NORMAS IETEKME UZ ZIEMAS RAPŠA (BRASSICA NAPUS L.) RAŽAS STRUKTŪRELEMENTU VEIDOŠANOS}

Kultūrauga ražu veido augu skaits platības vienībā un katra individuālā auga produktivitāte. Izsējas norma ietekmē augu skaitu platības vienībā, un tā, kā arī ziemas rapša sējas laiks var ietekmēt tādus ražas struktūrelementus kā pākstenu skaitu augam, sēklu skaitu pākstenī, sēklu skaitu un masu no auga, pirmās pakāpes zaru skaitu vienam augam. Latvijas Lauksaimniecības universitātes mācību un pētījumu saimniecībā "Vecauce" trīs gadus (2008-2010) veiktā pētījuma mērḳis bija vērtēt ziemas rapša ražas struktūrelementus atkarībā no sējas laika (pieci sējas laiki, sākot ar 1. augustu, un 10 dienu intervāls starp tiem) un izsējas normas (četras izsējas normas katrai škirnei), kas ir sākotnējais cēlonis augu biezībai novākšanas laikā. Pētījumā izmantoja divas atškirīgas šḳirnes: līnijškirni ‘Californium' un hibrīdo šķirni 'Excalibur'. Vairumā gadījumu rapša ražas struktūrelementu vērtības — pāksteṇu skaitu augam, sēklu skaitu pākstenī, auga produktivitāti (sēklu skaitu un sēklu masu no auga) un pirmās pakāpes zaru skaitu vienam augam abām izmantotajām škirnēm — būtiski ietekmēja abi pētāmie faktori $(p<0.05)$. Būtiska izsējas normas ietekme uz 1000 sēklu masu pārsvarā gadījumu netika atzīmēta $(p>0.05)$, bet sējas laiks šo parametru būtiski ietekmēja. Novēroja izteiktu ražas struktūrelementu kompensācijas mehānisma darbību, ko apliecināja konstatētās būtiskās $(p<0.05)$ negatīvās korelācijas starp augu biezību ražas novākšanas laikā un individuālo augu produktivitātes rādītājiem. 